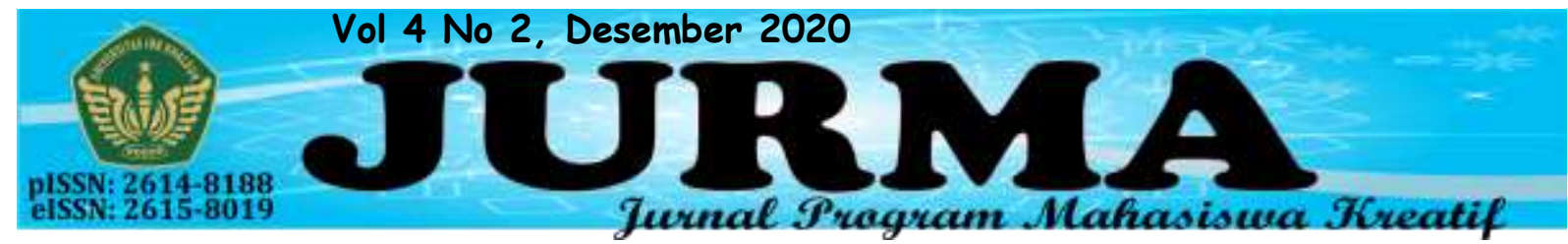

\title{
DIGITALISASI WARUNG SEMBAKO DAN TERINTEGRASI DENGAN PAYMENT GATEWAY BERBASIS SYARIAH
}

\author{
Ahmad Riswantio ${ }^{1}$ dan Abrista Devi ${ }^{2}$ \\ riswantio16@gmail.com ${ }^{1}$ \\ abristasmart@gmail.com ${ }^{2}$ \\ Fakultas Agama Islam Program Studi Ekonomi Syariah Universitas Ibn Khaldun Bogor 1,2
}

\begin{abstract}
ABSTRAK
Mitra dalam KKN Gagasan Tulis Mandiri ini adalah Usaha Mikro Kecil dan Menengah (UMKM) yang bergerak dalam bidang usaha retail atau warung sembako di Bantar Kemang Kota Bogor. UMKM yang menjadi mitra pengabdian ini belum lama membuka usahanya di bidang retail dan dari segi pemasarannya masih menggunakan cara yang konvensional. Karena itu UMKM ini perlu diberikan pelatihan mengenai digital marketing agar pemasarannya dapat lebih baik dan dapat memperluas cakupan pasarnya serta dapat menunjang kegiatan penjualan yang lebih baik. Selain itu, UMKM ini pun diberikan bantuan dalam membuat akun bisnis berupa Google Bisnis, Kerja sama dengan mitra yaitu WARKO Platform usaha retail online dan Mengintegrasikan dengan Payment Gateway Syariah, dan bantuan cara penggunaannya. Luaran atau hasil yang didapatkan adalah akun Google Bisnis, bermitra dengan WARKO, integrasi dengan Payment Gateway, dan artikel ilmiah yang diterbitkan dalam jurnal nasional. Metode yang digunakan dalam hal ini adalah ceramah, pendampingan dalam membuat akun, bermitra dengan warko dan mengitegrasikan dengan payment gateway, dan penyuluhan penggunaan sistem yang telah dibuat tersebut. Hasil dari pengabdian ini adalah ilmu dalam melakukan pemasaran secara digital dengan memanfaatkan teknologi yang telah ada untuk meluaskan target pasar, dan untuk membiasakan dalam new normal.
\end{abstract}

\section{Kata Kunci: UMKM, Retail, Payment Gateway Syariah, Digital Marketing}

\begin{abstract}
Partners in the Self-Writing Idea KKN are Micro, Small, and Medium Enterprises (MSMEs) which are engaged in retail business or grocery stalls in Bantar Kemang, Bogor City. MSMEs, which have become community service partners, have recently opened their business in the retail sector and from a marketing perspective, they still use conventional methods. Therefore, these MSMEs need to be given training on digital marketing so that their marketing can be better and can expand their market coverage and can support better sales activities. Also, these MSMEs were provided with assistance in creating business accounts in the form of Google Business, cooperation with partners, namely the WARKO online retail business platform and integrating with the Sharia Payment Gateway, and assistance on how to use it. The results obtained are a Google Business account, partnering with WARKO, integration to the Payment Gateway, and scientific articles published in national journals. The methods used in this case are lectures, assistance in creating accounts, partnering with
\end{abstract}


WARKO and integrating with payment gateways, and counseling on the use of the created system. The result of this service is the knowledge of doing digital marketing by utilizing existing technology to expand the target market, and to get used to the new normal.

\section{Keywords: MSMEs, Retail, Sharia Payment Gateway, Digital Marketing}

\section{PENDAHULUAN}

Tidak dapat dipungkiri bahwa salah satu kekuatan ekonomi atau salah satu penunjuang ekonomi negara Indonesia adalah pelaku usaha kecil, mikro dan menengah (UMKM). Karena UMKM mampu menyerap tenaga kerja lebih dari 90\% (BI 2015:32). Karna itu UMKM harus terus berdaya meskipun dalam keadaan sulit saat pandemi Covid-19 ini. Berdaya dengan cara terintegrasi dengan teknologi digital.

Pesatnya perkembangan teknologi sangat mengubah tatanan pemasaran didunia dalam kurun waktu terakhir ini. Metode pemasaran yang sebelumnya serba tradisional dan konvensional, sekarang telah terintegrasi dalam dunia digital (Ascharisa, 2018). Menurut Ashar (2006) pada konteks pelaku usaha kecil, peran teknologi informasi sangat penting mengingat kompetitor atau pesaing UMKM tidak hanya dari bisnis lokal atau regional tetapi telah melibatkan pelaku usaha bisnis berskala internasional. Pemasaran yang menggunakan teknologi digital disebut dengan digital marketing. E-Marketing atau digital marketing diartikan sebagai penggunaan teknologi digital untuk mencapai tujuan pemasaran serta upaya pengembangan atau penyesuaian konsep pemasaran itu sendiri, dapat berkomunikasi dalam cakupan global, dan mengubah cara perusahaan melakukan bisnis dengan pelanggan (Ali, 2013).

Menurut Sudaryanto dkk., penggunaan teknologi informasi dan komunikasi untuk pelaku UMKM dalam menggerakkan roda bisnis dapat memberikan fleksibilitas baik dalam produksi, menerima tawaran, dan mendukung transaksi cepat paperless. Untuk mendorong digitalisasi dan mempermudah UMKM dalam menghadapi pergeseran yang terjadi, pemerintah telah meningkatkan kemudahan akses dan melakukan transfer teknologi kepada pelaku UMKM agar tetap bertahan di dalam persaingan bisnis (Slamet et al., 2016).Kemampuan pemahaman perangkat digital dan internet ini merupakan hal yang harus dikuasaioleh UMKM jika ingin bertahan dalam persaingan (Purwana, Rahmi, \& Aditya, 2017).

Media digital yang dapat digunakan oleh pelaku UMKM adalah Google Bisnis. Google Bisnis ini aplikasi yang disediakan oleh Perusahaan Google LLC, aplikasi ini gratis dan dapat digunakan oleh pelaku UMKM untuk memajukan usahanya dan memasarkan produknya di dunia internet khususnya pada produk Google seperti Google Maps dan Google Penelusuran. Jika pelaku UMKM memasang lokasi bisnisnya pada Google Bisnis di lokasi tertentu, maka Google Bisnis dapat membantu calon pembeli menemukan usaha pelaku UMKM tersebut.

Media yang digunakan selain Google Bisnis yaitu Payment Gateway LinkAja. Payment Gateway LinkAja adalah suatu aplikasi dompet digital yang dapat digunakan untuk melakukan pembayaran 
secara digital, metode pembayaran digital ini sangat cocok dalam pencegahan covid19. Aplikasi LinkAja yang digunakan adalah LinkAja Syariah, perbedaan dari dompet digital yang lain adalah LinkAja Syariah fitur dan layanan uang elektronik yang dikelola sesuai kaidah syar'I sebagaimana difatwakan dalam Fatwa DSN MUI No.116/DSN-MUI/IX/2017.

Adapun Mitra dalam pelaksanaan KKN-Gagasan Tertulis Mandiri ini adalah Warung Sembako Cahya yang menjual keperluan dasar kehidupan manusia, berlokasi didaerah Bantar Kemang

\section{METODE PELAKSANAAN}

Kegiatan KKNGTM ini dilakukan kepada salah satu pelaku UMKM yang membuka usaha warung sembako, dengan alamat Jalan Durian 2 No.51 Rt 02 Rw 05 Kelurahan Baranangsiang Kecamatan Bogor Timur Kota Bogor. Pelaksanaan kegiatan ini dilakukan dengan cara interview, observasi dan pelatihan dan pendampingan.

Tahap pertama, yaitu tahap interview. Dalam interview ini kami memberikan pertanyaan mengenai atau yang berkaitan dengan situasi usaha responden semenjak pandemi covid-19. Jenis intetview yang digunakan penulis adalah interview persuasif bertujuan untuk
Baranangsiang Kota Bogor. Usaha tersebut terkena dampak pandemi covid-19 saat salah satu warga daerah tersebut ada yang terkna covid-19. Maka dari itu diperlukan sistem pemasaran online untuk memperluas cakupan target pasarnya dan juga untuk menunjang penjualan yang lebih baik.

Tujuan dari penelitian ini ialah untuk mengoptimalkan penjualan warung sembako cahya dengan menggunakan sistem digital marketing dan payment gateway untuk meminimalisir penularan covid-19.

mengetahui permasalahan yang dihadapi oleh narasumber dalam usaha yang dijalankannya.

Tahap kedua, adalah tahap observasi, dengan cara ini penulis dapat melihat langsung kondisi warung atau usaha mitra penulis. Sehingga penulis mendapatkan data yang akurat.

Tahap ketiga, ditahap ketiga ini peneliti memberikan pelatihan, pendampingan dan membantu praktik secara langsung atau membantu mendaftarkan UMKM kepada aplikasi media digital (Google Bisnis dan LinkAja Syariah) 


\section{HASIL PEMBAHASAN}

Dalam pengumpulan data ini, penulis menggunakan metode interview, observasi dan pelatihan/pendampingan sebagai tahap akhir dalam penelitian ini. Tahap pertama pengambilan data melalui interview, penulis mengajukan 3 pertanyaan yang berkaitan dengan usaha UMKM.

\begin{tabular}{|c|c|c|}
\hline No & Pertanyaan & Jawaban \\
\hline 1 & $\begin{array}{c}\text { Bagaimana penjualan di warung ibu } \\
\text { selama pandemic covid-19? }\end{array}$ & $\begin{array}{c}\text { Penjualan menurun, banyak penduduk disini } \\
\text { yang jarang keluar terutama anak-anak. }\end{array}$ \\
\hline 2 & $\begin{array}{c}\text { Jenis pembayaran apakah yang ada di } \\
\text { warung ibu? }\end{array}$ & $\begin{array}{c}\text { Tunai, selama ini masih menggunakan uang } \\
\text { tunai saja. }\end{array}$ \\
\hline 3 & Warung ibu apakah sudah go-online? & Belum, masih warung biasa. \\
\hline
\end{tabular}

Setelah mengajukan beberapa pertanyaan dalam interview, ditahap ke-2 ini yaitu tahap observasi. Dengan teknik penulis dapat melakukan pengambilan

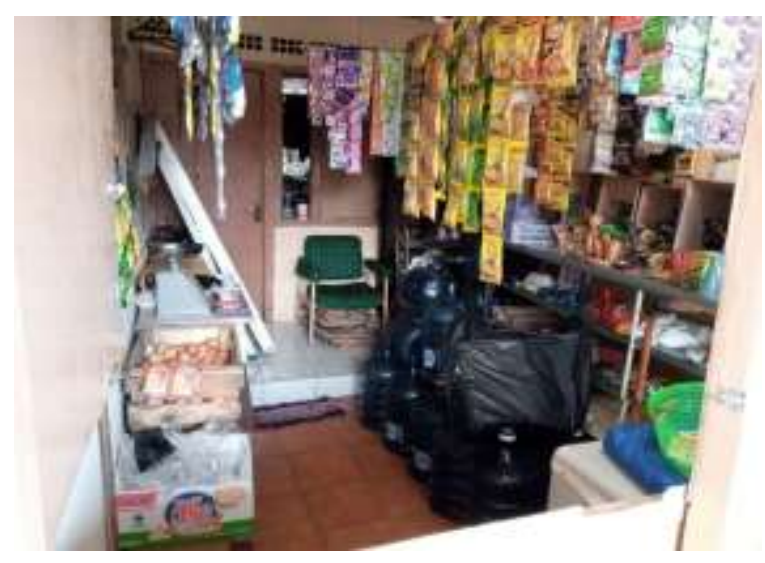

Gambar 1. Situasi Warung

Tahap ketiga ini, mulai melakukan pelatiahan, pendampingan dan pendaftaran warung kepada mitra yaitu Warko.id, Google Bisnis dan LinkAja.

1. Pendaftaran warung cahya kepada mitra yaitu Warko.id pada hari data secara relevan dan peniliti dapat langsung mengamati kondisi warung secara pasti.

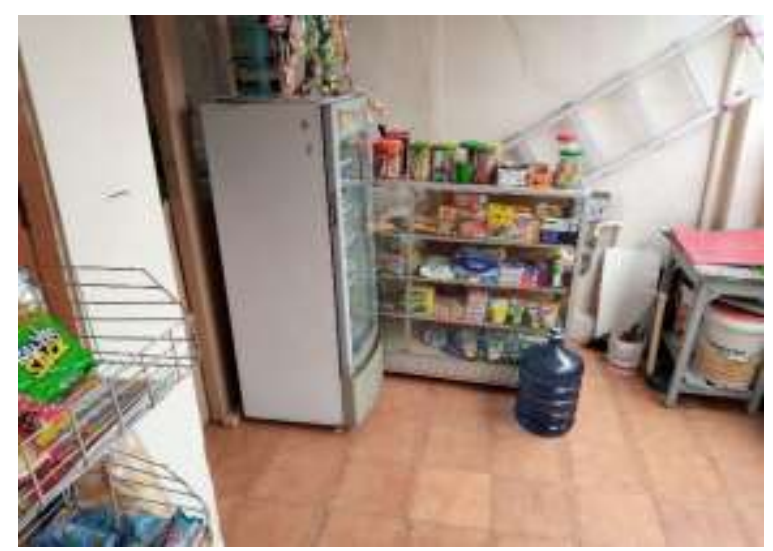

Gambar 2. Situasi Warung

Rabu, tanggal 16 September 2020. Pendaftaran mitra melalui online dengan mengisi form pada laman website: https://warko.id/daftarpengguna/. 


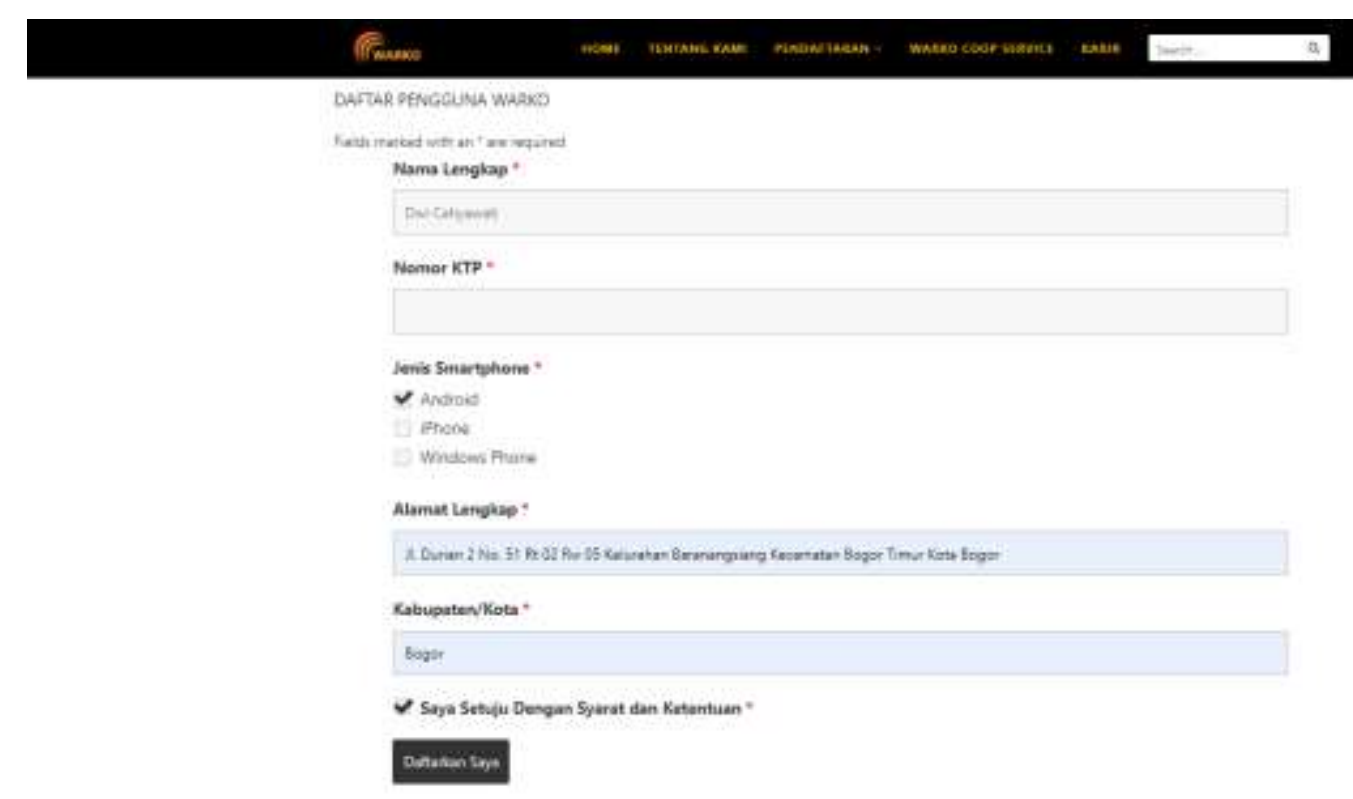

Gambar 3. Pendaftaran Mitra kepada Warko.id

2. Kemudian dilanjutkan dengan pelaksanaan kedua yaitu pelatiahan pembuatan akun Google Bisnis. Materi praktik langsung

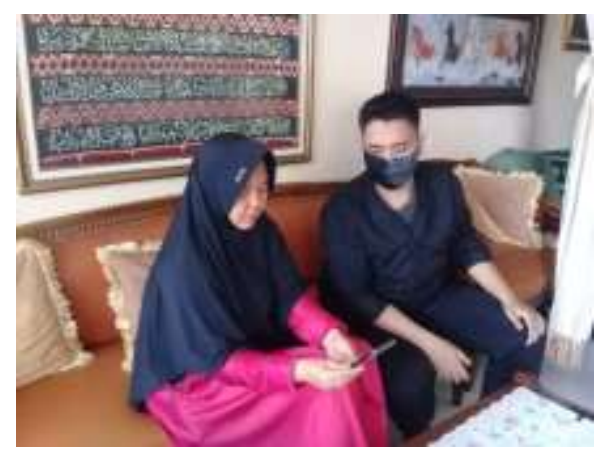

Gambar 4. Pelatihan \& Pendampingan Membuat akun Google Bisnis disampaikan oleh penulis langsung dan sekaligus pendampingan dalam membuat akun Google Bisnis.

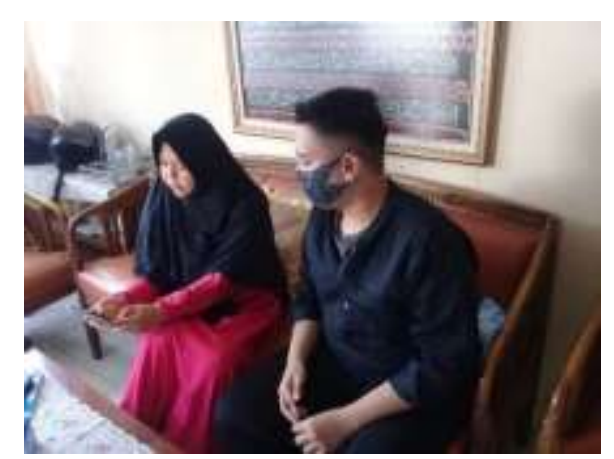

Gambar 5. Pelatihan \& Pendampingan Membuat akun Google Bisnis 


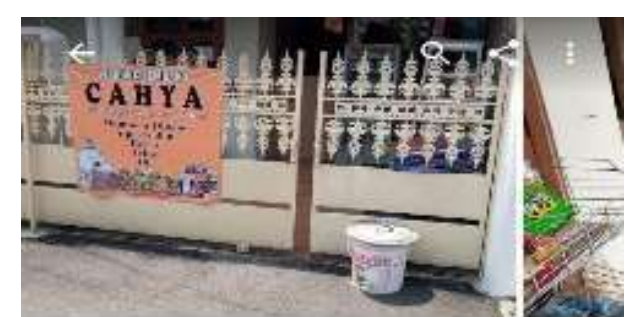

Warung Cahya (Tidak Jual Rokok)

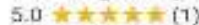

Conventenns stmes - Dpen

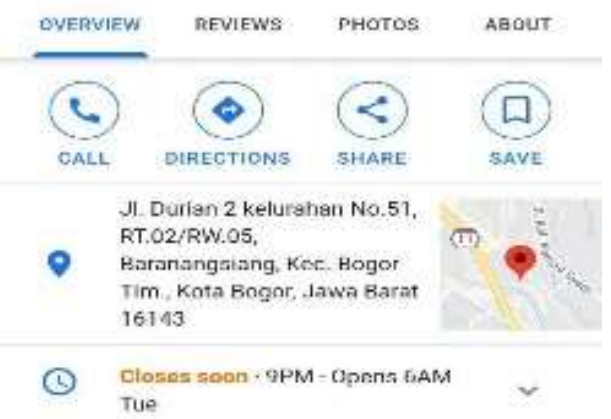

C. 0030-1921-2547

Gambar 6. Tampilan Google Bisnis

3. Terakhir kegiatan ini adalah pendaftaran payment gateway LinkAja lalu milih layanan Syariahnya. Payment gateway ini diperuntukan untuk membayar transaksi secara digital atau melalui dompet digital dan untuk mencegah penularan virus covid-19.
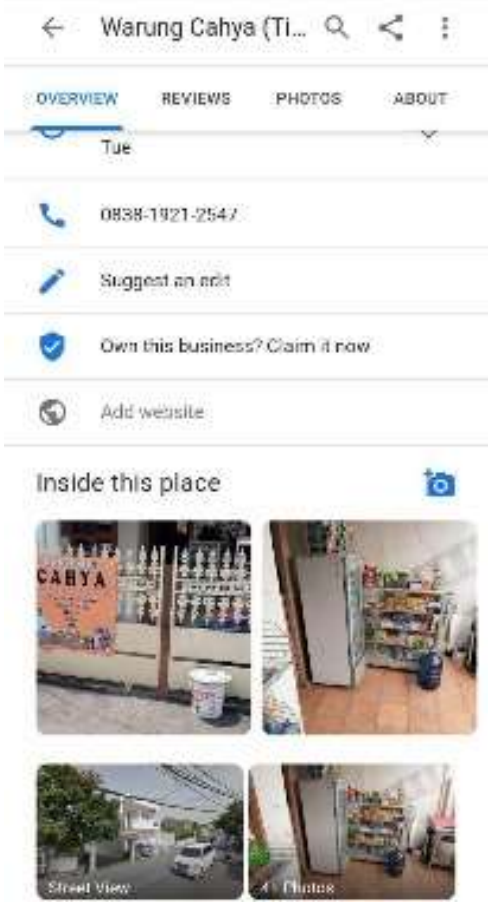

Gambar 7. Hasil Pelatihan membuat Google Bisnis

Registrasi akun LinkAja tidak memerlukan waktu yang lama kurang lebih 10 menit dan tinggal menunggu Barcode Merchant dari pihak LinkAja,barcode tersebut digunakan ketika pembeli akan membayar produk yang dibeli.

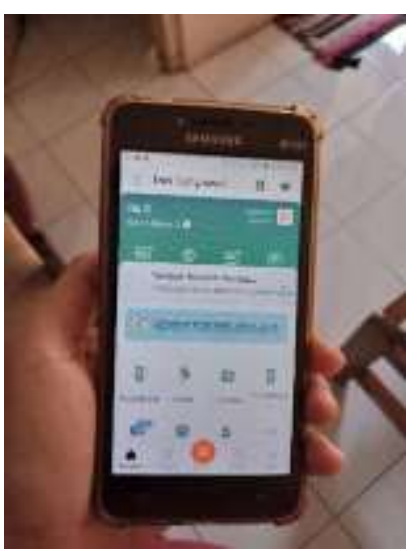

Gambar 8. Hasil Pendaftaran akun LinkAja Syariah 


\section{KESIMPULAN}

Hasil yang dapat didapatkan dalam kegiatan KKN - Gagasan Tertulis Mandiri dengan judul Digitalisasi Warung Sembako Dan Terintegrasi Dengan Payment Gateway Berbasis Syariah adalah Perkembangan teknologi saat ini sangatlah pesat khususnya digital, potensi yang luarbiasa yang Allah hadirkan didunia ini. Pelaku UMKM hendaknya memanfaatkan momentum ini dengan baik dengan memasarkan produknya didunia online agar produk dan tempat usahanya dapat diketahui oleh calon konsumen. UMKM salah satu sektor usaha yang sangat penting di Indonesia karena mampu menyerap tenaga kerja lebih dari 90\%. Tetapi masih banyak UMKM yang belum melakukan

\section{DAFTAR PUSTAKA}

Ascharisa Mettasatya Afrilia. 2018. Digital Marketing Sebagai Strategi Komunikasi. Jurkom, Riset Komunikasi 1 (1). Hal 147-157.

Ali, H. (2013). Marketing dan KasusKasus Pilihan. Yogyakarta: CAPS.

Baso Saleh, Yayat D. Hadiyat. (2016). Penggunaan Teknologi Informasi di Kalangan Pelaku Usaha Mikro KecilMenengah di Daerah Perbatasan(Studi di Kabupaten Belu Provinsi Nusa Tenggara Timur). Jurnal Pekommas, Vol. 1 No. 2, Oktober 2016: 141 - 152 .

Febriyantoro, M. T., \& Arisandi, D. (2018). Pemanfaatan digital marketing bagi usaha mikro, kecil dan menengah pada era masyarakat ekonomi ASEAN. Jurnal Riset pemasaran secara digital dan belum mengerti sebarapa besarnya manfaatnya pemasaran secara digital atau online.

Hasil yang dapat didapatkan dalam kegiatan KKN - Gagasan Tertulis Mandiri yaitu pemberian pelatihan mengenai pemasaran digital marketing sebagai pemasaran produk yang dijual. Pelatihan dan pendampingan nya berupa pendaftaran kepada warko.id sebagai mitra penjualan warung narasumber, pembuatan akun Google Bisnis dan pendaftaran payment gateway LinkAja untuk media pembayaran secara digital. Ketiga media tersebut sebagai saran promosi untuk mengoptimalkan penjualan produk yang lebih baik.

Manajemen dan Bisnis Dewantara (JMD), 1(2), 61-76.

Lembaga Pengembangan Perbankan Indonesia, Bank Indonesia. (2015). Profil Bisnisusaha Mikro, Kecil Dan Menengah (Umkm). Jakarta.

Idah, Y. M., \& Pinilih, M. (2020). STRATEGI PENGEMBANGAN DIGITALISASI UMKM. Prosiding, 9(1).

NAIMAH, R. J., WARDHANA, M. W., HARYANTO, R., \& PEBRIANTO, A. (2020). Penerapan Digital marketing Sebagai Strategi Pemasaran UMKM. Jurnal IMPACT: Implementation and Action, 2(2), 39-50.

Prasetya, E. (2018). Pemberdayaan Masyarakat Tentang Kesehatan, 
Pendidikan dan Kreatifitas. Abdi

Dosen: Jurnal Pengabdian Pada Masyarakat 2 (1), 19-25.

Purwana, D., Rahmi, \& Aditya, S. 2017. Pemanfaatan Digital Marketing Bagi Usaha Mikro, Kecil,dan Menengah (UMKM) Di Kelurahan Malaka Sari, Duren Sawit. Jurnal PemberdayaanMasyarakat Madani (JPPM) 1(1): 1 - 17

Slamet, R., Nainggolan, B., Roessobiyatno, Ramdani, H., Hendriyanto, A., \&
Lu'ul, I. L. 2016.Strategi Pengembangan UKM Digital Dalam Menghadapi Era Pasar Bebas. JurnalManajemen Indonesia 16(2): $136-147$

Internet:

Sudaryanto, Ragimun, , R. R. (Tanpa Tahun). StrategiPemberdayaan UMKM Menghadapi Pasar Bebas Asean. Diakses dari laman http://www.kemenkeu.go.id/sites/def ault/files/Strategi\%20Pemberdayaan \%20UMKM.pdf 